\title{
GIS-based landslide susceptibility zonation for roadside slope repair and maintenance in the Himalayan region
}

\author{
1 Graduate School of Science and Engineering, Ehime University, Bunkyo-cho 790-8577, Matusyama City, Ehime, Japan. \\ E-mail:pantha.bhoj.06@cee.ehime-u.ac.jp,panthabhoj@gmail.com \\ 2 Faculty of Engineering, Ehime University, Matsuyama, Japan.
}

\begin{abstract}
Roadside slope failure is a common problem in the Himalayan region as road construction activities disturb natural slopes. Therefore, landslide susceptibility zonation is necessary for roadside slope disaster management and planning development activities. In this study, we consider a 53-km section of a major highway in Nepal where road services are suspended for several days in the monsoon season every year. A number of methods have been used for landslide susceptibility zonation. We employed a bivariate statistical approach for this study. Relevant thematic layer maps representing various factors (e.g., slope, aspect, land use, lithology, drainage density, proximity to stream and proximity to road) that are related to landslide activity, have been prepared using Geographic Information System (GIS) techniques. A total of 277 landslides (covering a total of $29.90 \mathrm{~km}^{2}$ ) of various dimensions have been identified in the area. A landslide susceptibility map was prepared by overlaying a landslide inventory map with various parameter maps segmented into various relevant classes. The landslide susceptibility index was segmented into five zones, viz. very low, low, moderate, high and very high susceptibility. Landslide susceptibility zonation maps are useful tools for the efficient planning and management of roadside slope repair and maintenance tasks in the Himalayan region.
\end{abstract}

\section{Introduction}

Landslides are the major destructive phenomena in hilly mountainous terrain such as in Nepal. Infrastructure construction such as roads in such terrain may cause adverse impacts on slope stability. Naturally formed slopes are disturbed by road construction activities. Being largely natural material, there is more inherent variability to their engineering performance and sensitivity to long-term degradation or changes than is exhibited by other materials (largely manufactured) used to construct other elements of the highway network. However, the consequences of their response can significantly influence the safety, environment, performance and whole life cycle cost of highways. The scale of the problem ranges from one of the most devastating geo-hazards with threats to life and economies, to one of nuisance requiring increased maintenance costs only. The task of effective and optimal resource allocation for road repair and mainte- nance is typically complex and requires a time-subjective undertaking. Therefore, assessment of slope risk and its proper management is crucial in all project stages. In general, geotechnical and geological investigations, identification of geologically hazardous areas and proper design of mitigation measures are the basic steps for slope risk management during the stages of project planning and design. However, after construction of roads in the Himalayan region, slope failure problems increase substantially. There may be two reasons: (a) road alignment passes through the existing landslide area, (b) new road alignment disturbs natural balances. Siddle et al. (2006) have well documented the phenomena of increment in occurrence of landslides along new road corridors. In addition, the construction of new roads may cause changes in the dynamics of local societies as economic activity is restructured to take advantage of the new opportunities presented by the road. Thus, in many cases there is a relocation of the population to live beside the road, which might lead to increased vulnerability and changes in land use, including, in some cases, the abandonment of the terrace cultivation systems. These changes might well lead to an increase in landslide impacts (Petley et al., 2007). Construction and maintenance of roads in mountainous terrain are difficult, particularly in geologically young and tectonically active regions. Intense and prolonged rainfall leads to local high groundwater tables, saturated soils and large quantities of surface runoff during the wet season. These problems are usually compounded by landsliding, erosion, slope failure, river/stream flooding and river incision. Sidle et al. (2006) have demonstrated that the density of landslides associated with road construction in mountainous terrains is one, and in some cases two orders of magnitude greater than for other land use changes. A similar conclusion was drawn by Petley et al. (2007), who studied the growth of rural road networks and associated landslides in Nepal. They found that underlying trend of landslide occurrence coincides with the trend of rural road network expansion. However, the number of landslides that Petley et al. (2007) considered includes both large-scale landslides and shallowsheeted landslides, including debris flows. It is a fact that debris flows and mud flows usually occur in the areas subjected to largescale landslide during intense rainfall. Therefore, assessing slope instability along roads is important for sustainable roadside slope risk management.

Some efforts have been made in the field of landslides in Nepal. The Government of Nepal has established the Department of WaterInduced Disaster Prevention (DWIDP) to deal with water-induced disasters like landslides and floods. Similarly, the Department of Roads has established a separate geo-environmental unit to deal with roadside slope protection work. However, preparation of a landslide susceptibility map to be incorporated in infrastructure planning and maintenance has not been done yet. Some studies have been done on landslide mapping. However, there are very few efforts being made in landslide susceptibility zonation. Most landslide susceptibility zonation has been done by the qualitative approach. Some of the prominent research into landslides in Nepal are Hearn et al., (1997); Deoja et al., (1991); Upreti, (2001); Upreti and Dhital, (1996); Dhital, (2003), Dhital et al., (1993); Yatabe et al., (2005); Acharya et al. 
(2006); and Pathak and Nilsen, 2004. The aim of this study is to prepare a landslide susceptibility zonation map along a selected section of highways by employing the bivariate statistical approach (InfoValue method) in GIS environment. The purpose of preparing this landslide susceptibility zonation map is to incorporate road slope risk management into an integrated road maintenance prioritization model. In this study, we attempt to produce a landslide susceptibility map along a $53-\mathrm{km}$ section of road in central Nepal. We believe that such a map will be useful for road repair and maintenance planning.

\section{Landslide susceptibility mapping: bivariate statistical approach}

Landslide susceptibility mapping has been defined by Guzzetti et al. (1999) as the quantitative prediction of the spatial distribution of both deposits and slopes that are likely to be failure sites, whose movement or reactivation will take place in a way and within a time period defined from information that is not directly incorporated in the analysis. Many qualitative and quantitative methods have been used to evaluate landslide susceptibility at the basin scale, including statistical approaches, heuristic approaches, direct geomorphological mapping and physically based models. With the advance of GIS analytical capability, many new and sophisticated methods have evolved, such as analytical hierarchy process (AHP), bivariate statistical approach, multivariate statistical approach, logistic regression, fuzzy logic and artificial neural network, and used for landslide susceptibility assessment (Yalcin, 2008; Guzzetti et al., 1999; Ayalew and Yamagishi, 2005; van and Westen, 1997).

The quantitative methods are based on numerical expressions of the relationship between controlling factors and landslides. This method includes deterministic and statistical approaches (Aleotti and Chowdhery, 1999). Landslide susceptibility mapping using either multivariate or bivariate statistical approaches analyzes the historical link between landslide controlling factors and distribution of landslides (Guzzeetti et al., 1999). This analysis involves the idea of comparing a landslide inventory map with the maps of landslide influencing parameters in order to rank the corresponding classes according to their role in landslide formation (Ayalew and Yamagishi, 2005). However, there are no universal guidelines for selecting the influencing parameters (Yalcin, 2008). It mainly depends on the availability of data and significance of the parameters in a particular area. The bivariate statistical approach (InfoValue method) is also known as the statistical index (Wi) method. In the statistical index (Wi) method, a weight value for a parameter class is defined as the natural logarithm of the landslide density class, divided by the landslide density over the entire map (van Westen, 1997). This method is based on the following formula:

$$
W i=\ln \frac{\text { Densclass }}{\text { Densmap }}=\ln \frac{\text { Npix }(\text { Si }) / \text { Npix }(\mathrm{Ni})}{\sum_{i=1}^{n} N \operatorname{Nix}(\mathrm{Si}) / \sum_{i=1}^{n} N p i x(\mathrm{Ni})}
$$

where $W i$ is the weight given to the $i^{\text {th }}$ class of a particular thematic layer (e.g., 10 to 20 degree in the thematic layer 'slope'); Densclass is the landslide density within the parameter class; Densmap is the landslide density within the entire map; $N p i x(S i)$ is the number of pixels, which contain landslides, in a certain parameter class; $N p i x(N i)$ is the total number of pixels in a certain parameter class, and $n$ is the number of classes in a thematic map. The natural logarithm is used to accommodate the large variation in the weights.

Thus, the weight is calculated for various classes in each thematic. The thematic is then overlaid and added to prepare a final landslide susceptibility index. The landslide susceptibility index is divided into a relevant number of zones to produce a landslide susceptibility zonation map. The boundaries may be adjusted subjectively to refine the suitable landslide hazard map (van Westen, 1997).

\section{The study area}

The study area is located in central Nepal (Figure 1). It covers a total length of $53.2 \mathrm{~km}$ including parts of both the Prithvi and Mugling-Narayanghat highways. The Prithvi highway is the only major highway that connects the capital city Kathmandu to the other parts of the country. Similarly, the Mugling-Narayanghat highway is the linkage between the Prithvi and Mahendra highways (eastwest highway), which pass through the southern belt of Nepal. This stretch of highway suffers from frequent slope failure problems. As a result, road services are disrupted for several days because of landslides and debris flows along this stretch. A large amount of road property (pavement and road structures) is also lost every year because of landslides and debris flows in the area. The total studied area is about $337.62 \mathrm{~km}^{2}$. Due to the lack of information on potential failure sites, road clearance equipment is not properly placed
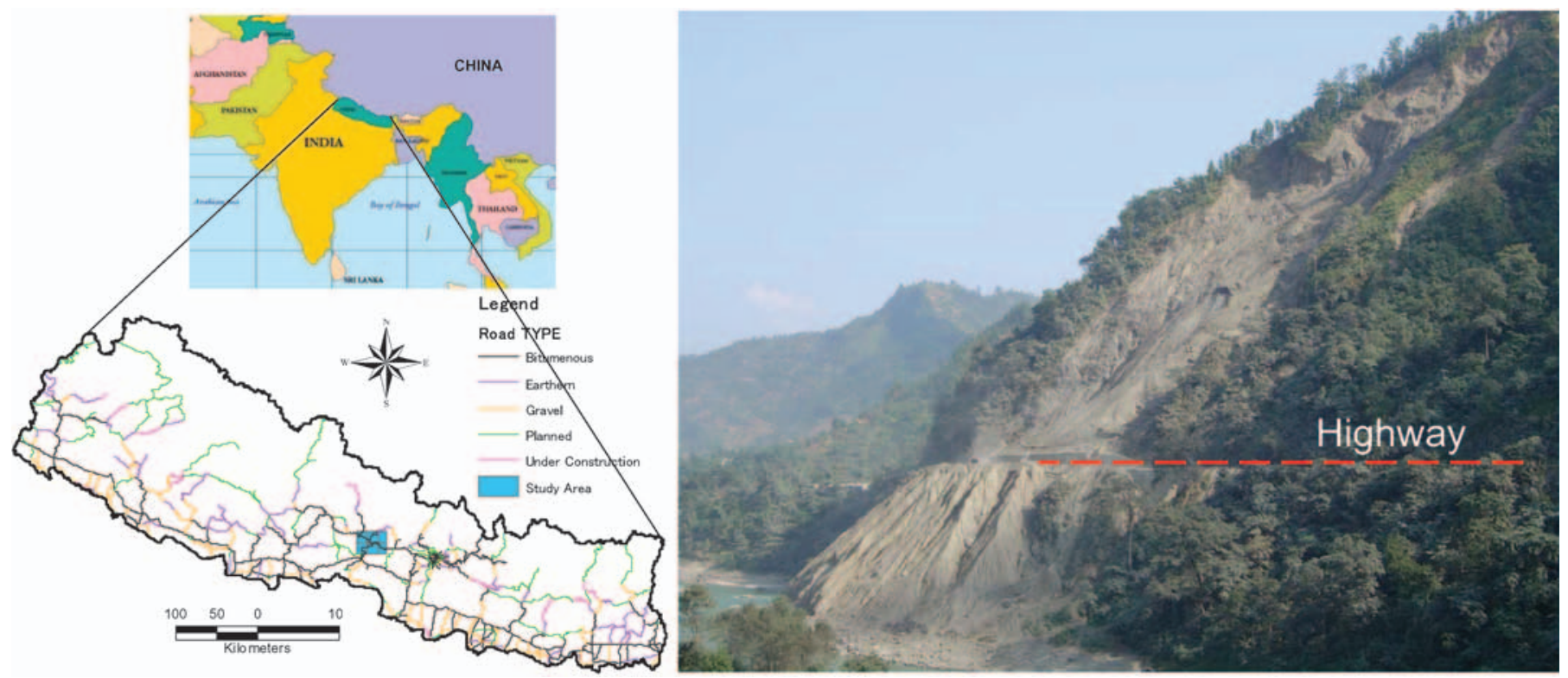

Figure 1 The study area: (a) location map, (b) typical landslide in the study area. 
and pre-monsoon failure prevention strategies are not well considered.

Geologically, the study area lies in the Lesser Himalayan Zone, with rocks ranging in age from Upper Precambrian to late Paleozoic (Stocklin and Bhattarai, 1977). The Lower and Upper Nawakot Group, consisting of a wide variety of rock types such as phyllites, quartzites, dolomites, and amphibolites, are the dominant rock formations. Several major fault/thrust lines pass through the area. The average annual rainfall is more than $1800 \mathrm{~mm}$. The study area is comprised of 45 drainage basins of various sizes. Many streams of different orders (1st-5th) dissect the area along both sides of highway. The total length of the streams is $1,268 \mathrm{~km}$. The average drainage density of the area is about $3.65 \mathrm{~km} / \mathrm{km}^{2}$. The Trishuli River flows from the middle of the study area. The selected stretches of highway run along the left bank of this river, and also along the foot of the hills. The altitude ranges from $200 \mathrm{~m}$ to $1880 \mathrm{~m}$. Seven different types of land-use patterns exist in this area, of which cultivated land makes up the highest percentage (48\%).

\section{Material and method}

Different kinds of data related to landslides and their controlling factors were collected. The basic data, such as elevation, river system, land use, transportation network and aerial photographs were collected from the Department of Survey, Nepal. Commercially available ArcGIS 9.0 software was employed to prepare different layer maps required for producing the landslide susceptibility map. All digital data were georeferenced by means of the common coordinate system (Nepal Central; Datum: Everest Bangladesh, Spheroid: Everest adjustment 1937, Projection: Transverse Mercator, Central meridian: 84.0, and Scale factor: 0.9999). The study area was delineated in such a way that it covers at least one complete drainage basin on each side of the highway. A geological map prepared by Stocklin and Bhattarai (1977), covering the study area, was reproduced in digitized form. Landslide inventory of the area was produced from 1:50,000 aerial images taken in 1992 and 1:25,000 topographical maps of the study area. As the landslides were identified from interpretation of aerial photographs and topographical maps, all landslides are active, large-scale, slow-moving, creep-type landslides. These landslides include both earthquake- and rainfallinduced ones, and were not separated into new or old. The influencing parameters selected for susceptibility mapping in this particular study include slope, aspect, land use, lithology, drainage density, proximity to streams and proximity to roads. All raster-based analysis was performed in $10 \mathrm{~m}$ pixel. The Digital Elevation Model (DEM) of the study area was produced using a topographical map. Slope and aspect layer were created from DEM. Land-use pattern was derived from topographical maps. Drainage basins were delineated on a topographical map. Moreover, drainage density in each drainage basin was computed. As drainage density is the ratio of the total length of the stream to the area of the drainage basin, the drainage density was computed by dividing the total length of a stream within a drainage basin by the area of that drainage basin. Stream ordering was done according to the Horten-Strahler network ordering method. Proximity to streams and roads was computed using a spatial analyst tool of ArcGIS 9.0. Since raster dataset has enriched capability for spatial analysis, all parameter layers were converted into raster images.

The bivariate statistical approach was employed in this study. This approach requires the selection and mapping of significant parameters and their categorization into a number of relevant classes, landslide inventory mapping, overlay mapping of the landslide inventory map with each parameter map, determination of density of landslide in each parameter class and definition of weighted values. Details of categorization of each parameter are presented in subsequent figures and paragraphs. The weighted value of the classes used to categorize every parameter is determined on the basis of landslide density in each individual class. In the statistical index (Wi) method; a weight value for a parameter class is computed as in Eq. (1). The statistical index of each parameter class was calculated using the raster calculator. Finally, all the weighted parameter maps were added according to Eq. (2) and a susceptibility index (LSI) map was produced.

$$
L S I=W i S l+W i A s+W i L u+W i L i+W i D d+W i P s+W i P r
$$

where WiSl, WiAs, WiLu, WiLi, WiDd, WiPs and WiPr are distribution-derived weights for slope, aspect, land use, lithology, drainage density, proximity to streams and proximity to roads, respectively. The susceptibility scores were finally reclassified into very low, low, moderate, high, and very high susceptibility, based on standard deviation (Yalcin, 2008; Ayalew et al., 2005). To test the reliability of the landslide susceptibility map produced in this study, the landslide inventory map and susceptibility map were statistically compared.

\section{Result and discussion}

\section{Landslide distribution map}

The identification and mapping of existing landslides is a prerequisite for performing statistical analysis of the relation between the distribution of landslides and influencing parameters. The reliability and accuracy of the landslide inventory map also influence the success of applied methodology. Since it is not possible to reach all places to locate every landslide in mountainous regions such as the Himalayas, aerial photographs and remote sensing images are usually important sources of information, as they provide a synoptic view of the landscape. However, satellite images are also used. A total of 277 landslides $\left(29.90 \mathrm{~km}^{2}\right)$ of various dimensions have been identified in the area using both aerial photographs (with the help of stereoscope) and topographical maps. From Figure 2 it can be observed that landslides are densely located in the vicinity of the highways. Figure 3 shows the distribution of landslides on either side of the highways. In Nepal, the practice of keeping records of

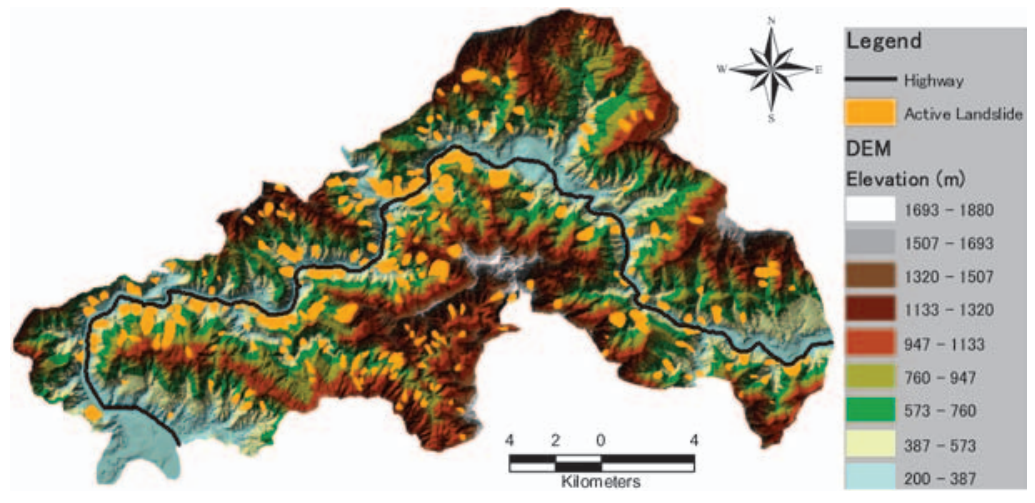

Figure 2 Landslide inventory map.

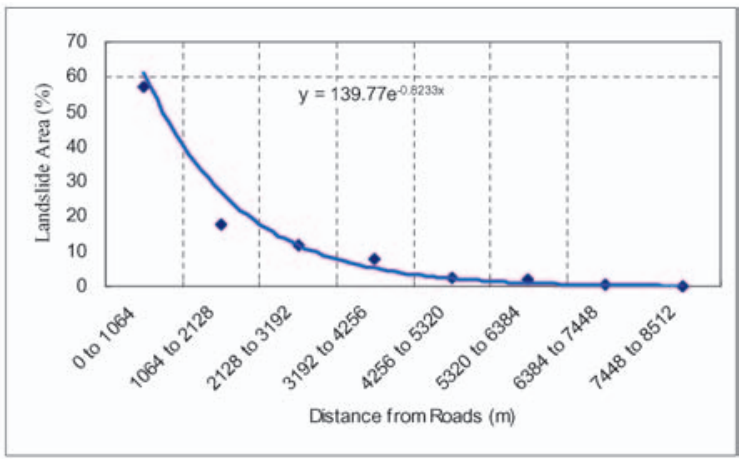

Figure 3 Spatial distribution of landslides in transverse direction of highways. 


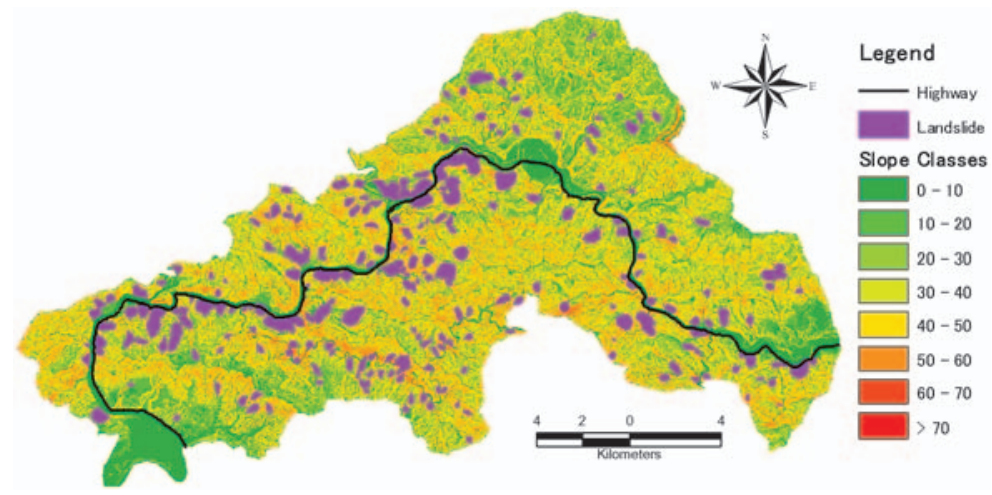

Table 1 Slope classes, landslides and Wi value.

\begin{tabular}{|c|c|c|c|}
\hline Parameter & $\begin{array}{l}\text { Parameter } \\
\text { Class(degree) }\end{array}$ & $\begin{array}{l}\text { Landslide } \\
\text { Area (\%) }\end{array}$ & $\begin{array}{c}\text { Statistical } \\
\text { Index (Wi) }\end{array}$ \\
\hline \multirow{5}{*}{ Slope } & $0-10$ & 3.64 & -1.2551 \\
\cline { 2 - 4 } & $10-20$ & 6.04 & -0.2211 \\
\cline { 2 - 4 } & $20-30$ & 27.54 & 0.2358 \\
\cline { 2 - 4 } & $30-40$ & 34.12 & 0.1577 \\
\cline { 2 - 4 } & $40-50$ & 19.33 & 0.0209 \\
\cline { 2 - 4 } & $50-60$ & 7.38 & -0.0395 \\
\cline { 2 - 4 } & $60-70$ & 1.77 & -0.0844 \\
\cline { 2 - 4 } & $>70$ & 0.19 & -0.3527 \\
\hline
\end{tabular}

Figure 4 Distribution of landslides with variation in slopes classes.

landslides with detailed information is almost non-existent. Therefore, it is very difficult to determine the exact year of a landslide occurrence. Thus, there might be two possible reasons why landslides are so densely distributed along highways: (1) the highways have been constructed on landslide zones; (2) road construction accelerates the movement of slow-moving masses or reactivates the stabilized old landslides as the highways were constructed at the foot of the mountains. The aerial photographs used in this study were taken in 1992. The Prithvi highway and Mugling-Narayanghat highway were constructed in 1974 and 1982, respectively. Therefore, the second reason cannot be completely ignored.

\section{Landslide influencing parameter maps}

Many environmental factors pertaining to the fields of geology, geomorphology, hydrology and land use have the potential to influence landsliding. A large set of instability factors is typically used in scientific literature to analyse landslide hazards. However, the significance of a particular parameter depends on site-specific conditions. The following seven types of parameters are considered as influencing parameters in landslides in this study;

\section{Slope}

Slope angle is the most substantial cause of landsliding. Because of the direct relationship between slope angle and landslide, it is frequently used in preparing landslide susceptibility maps (Yalcin, 2008; Thiery et al., 2007; Conoscenti et al., 2007; Komac, 2006; Ayalew et el., 2005; Guzzetti et al., 2006; Eeckhaut et al., 2006; Eranoglu and Gokceoglu, 2004; Lee et al., 2004b; Ermini e al., 2005; Suzen and Doyuran, 2004; Ayalew and Yamagishi, 2005; Lan et el., 2004; Dai et al., 2001; Lee and Min, 2001; Clerici et al., 2002 etc.). The slope classes, percentage of landslides in each class and respective statistical indices are shown in Figure 4 and Table 1. Table 1 indicates that about $60 \%$ of landslides occur at a slope angle between 20 and 40 degrees. It is a fact that less landslides occur on mild and steep slope angles.

\section{Aspect}

Aspect is also an important influencing factor, and frequently used in landslide-susceptibility mapping (Yalcin, 2008; Thiery et al., 2007; Conoscenti et al., 2007; Komac, 2006; Ayalew et al., 2005; Guzzetti et al., 2006; Eeckhaut et al., 2006; Eranoglu and Gokceoglu, 2004; Lee et al., 2004b; Ermini et al., 2005; Suzen and Doyuran, 2004; Ayalew and Yamagishi, 2005; Lan et el., 2004; Dai et al., 2001; Lee and Min, 2001; Clerici et al., 2002; Guzzetti et al., 1999). Aspect identifies the steepest downslope direction from each cell to its neighbors. Aspect-related parameters such as exposure to sunlight, drying winds, rainfall (degree of saturation), and discontinuities may control the occurrence of landslides. The aspect classes, percentage of landslides in each class and respective statistical indices are shown in Figure 5 and Table 2. Analysis shows that about $30 \%$ of landslides occur in northeast and north aspect classes.

\section{Land use}

Land use is also one of the key factors responsible for the occurrence of landslides, since barren slopes are more prone to landslides. The major causes of erosion in the Himalayas are deforestation, improper cultivation, overgrazing and construction work, which all damage the environmental balance. Soil with sparse vegetation is more susceptible to erosion. Improper and haphazard cultivation enhance slope instability. The infiltration rate in cultivated land is high. Bare soil erodes rapidly. If water is moving on top of the soil, it has a greater ability to move loose soils and rocks. Land-use changes like replacement of forest and agricultural land to road and other infrastructure is an important factor in triggering landslides. The land-use type, percentage of landslide in each class and respec-
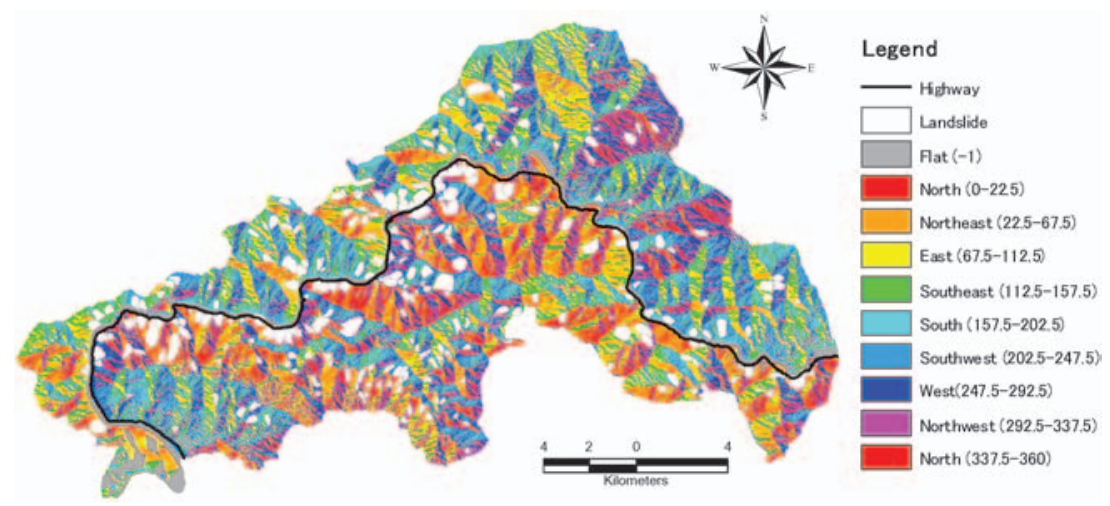

Table 2 Aspect classes, landslides and Wi value.

Figure 5 Distribution of landslides with variation in aspect classes.

\begin{tabular}{|c|l|r|c|}
\hline Parameter & $\begin{array}{l}\text { Parameter } \\
\text { Class }\end{array}$ & $\begin{array}{l}\text { Landslide } \\
\text { Area (\%) }\end{array}$ & $\begin{array}{c}\text { Statistical } \\
\text { Index (Wi) }\end{array}$ \\
\hline \multirow{5}{*}{ Aspect } & Flat & 4.51 & -0.9277 \\
\cline { 2 - 4 } & North & 16.39 & 0.4560 \\
\cline { 2 - 4 } & Northeast & 12.84 & 0.1722 \\
\cline { 2 - 4 } & East & 9.31 & -0.0901 \\
\cline { 2 - 4 } & Southeast & 9.80 & -0.2057 \\
\cline { 2 - 4 } & South & 12.19 & 0.0081 \\
\cline { 2 - 4 } & Southwest & 11.86 & 0.0096 \\
\cline { 2 - 4 } & West & 8.95 & -0.1255 \\
\cline { 2 - 4 } & Northwest & 14.16 & 0.2346 \\
\hline
\end{tabular}




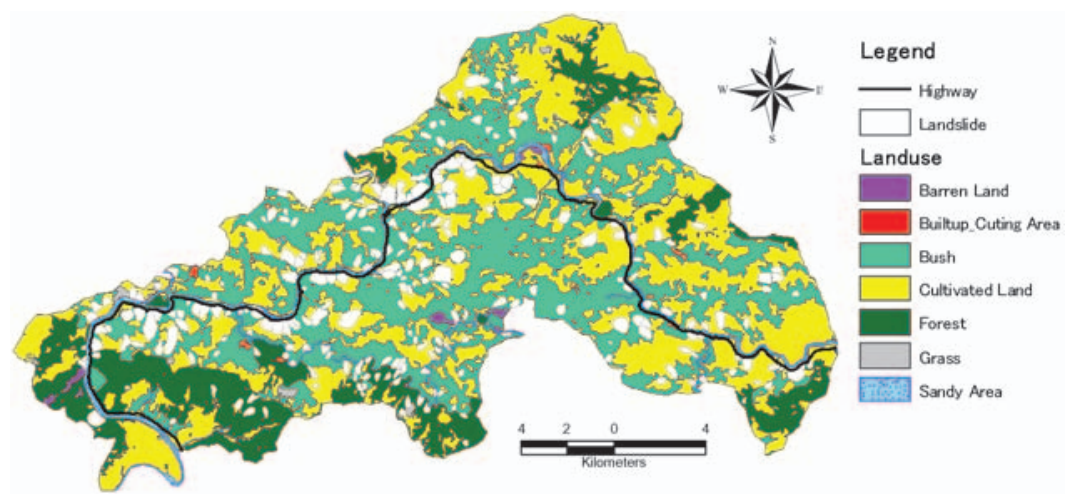

Table 3 Land use classes, landslides and Wi value.

\begin{tabular}{|l|l|r|c|}
\hline Parameter & $\begin{array}{l}\text { Parameter } \\
\text { Class }\end{array}$ & $\begin{array}{l}\text { Landslide } \\
\text { Area (\%) }\end{array}$ & $\begin{array}{c}\text { Statistical } \\
\text { Index (Wi) }\end{array}$ \\
\hline \multirow{7}{*}{ Landuse } & Bush & 42.09 & 0.0915 \\
\cline { 2 - 4 } & Forest & 7.63 & -0.6638 \\
\cline { 2 - 4 } & Grass & 1.91 & 1.1372 \\
\cline { 2 - 4 } & Cultivat. land & 47.72 & 0.1076 \\
\cline { 2 - 4 } & Barren land & 0.05 & -2.0864 \\
\cline { 2 - 4 } & Builtup area & 0.32 & -0.0052 \\
\cline { 2 - 4 } & Sandy area & 0.28 & -2.2280 \\
\hline
\end{tabular}

Figure 6 Distribution of landslides with variation in land-use type.

tive statistical indices are presented in Figure 6 and Table 3. From analysis it is found that more than $47 \%$ of landslides occur in cultivated land.

\section{Drainage density}

In mountainous regions drainage density provides an indirect measure of groundwater conditions, which have an important role to play in landslide activity. Generally, the higher the drainage density, the lower the infiltration and the faster the movement of the surface flow (Pachauri et al., 1998; Nagarajan et al., 2000; Cevic and Topal, 2003; Yalcin, 2008). This is because, the higher the drainage density, the denser the stream network, and surface flow accumulates to the nearest stream very quickly. This phenomenon reduces the amount of infiltration, and ultimately sustains the soil strength as its initial condition. The drainage density classes, percentage of landslide in each class and respective statistical indices are presented in Figure 7 and Table 4 . There are altogether 45 drainage basins in the area. The total length of the streams in the area is $1,268 \mathrm{~km}$. The drainage basins are grouped into eight classes according to size of the drainage basins. It was found that about $60 \%$ of landslides occur in the basins with drainage density varying between 2.98 and $3.69 \mathrm{~km}^{-1}$.

\section{Proximity to stream}

An important parameter that controls the stability of a slope is the saturation degree of the material on the slope (Yalcin, 2008). The closeness of the slope to drainage structures is another important factor in terms of stability. Streams in the Himalayan region have swift currents. Thus, streams may adversely affect stability by eroding the slopes or by saturating the lower part of material, resulting in water level increases (Gokceoglu and Aksoy, 1996; Dai et al., 2001; Cevic and Topal, 2003; Yalcin, 2008). The distance to stream classes, percentage of landslide in each class and statistical indices are presented in Figure 8 and Table 5. Analysis shows that about $72 \%$ of landslides occur within $150 \mathrm{~m}$ of the streams.

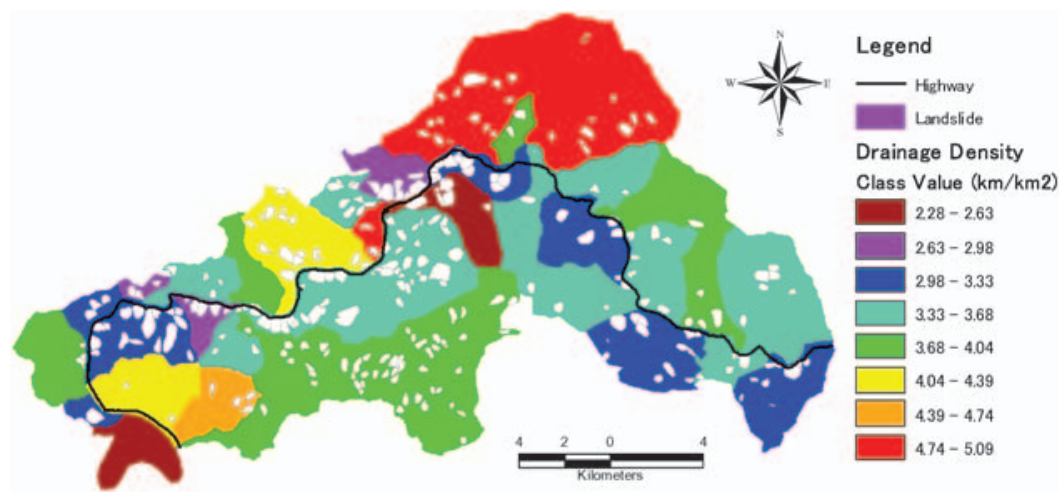

Figure 7 Distribution of landslides with variation in drainage density classes.
Table 4 Drainage density classes, landslides and Wi value.

\begin{tabular}{|l|l|c|c|}
\hline Parameter & $\begin{array}{l}\text { Parameter } \\
\text { Class }\left(\mathrm{km} / \mathrm{km}^{2}\right)\end{array}$ & $\begin{array}{l}\text { Landslide } \\
\text { Area (\%) }\end{array}$ & $\begin{array}{l}\text { Statistical } \\
\text { Index (Wi) }\end{array}$ \\
\hline \multirow{4}{*}{$\begin{array}{c}\text { Drainage } \\
\text { Density }\end{array}$} & $2.28-2.63$ & 3.74 & -0.1485 \\
\cline { 2 - 4 } & $2.63-2.98$ & 7.52 & 0.9195 \\
\cline { 2 - 4 } & $2.98-3.33$ & 29.11 & 0.6004 \\
\cline { 2 - 4 } & $3.33-3.69$ & 29.47 & 0.0248 \\
\cline { 2 - 4 } & $3.69-4.04$ & 14.79 & -0.4751 \\
\cline { 2 - 4 } & $4.04-4.39$ & 6.01 & -0.1667 \\
\cline { 2 - 4 } & $4.39-4.74$ & 1.37 & -0.4095 \\
\cline { 2 - 4 } & $4.74-5.09$ & 7.98 & -0.6303 \\
\hline
\end{tabular}

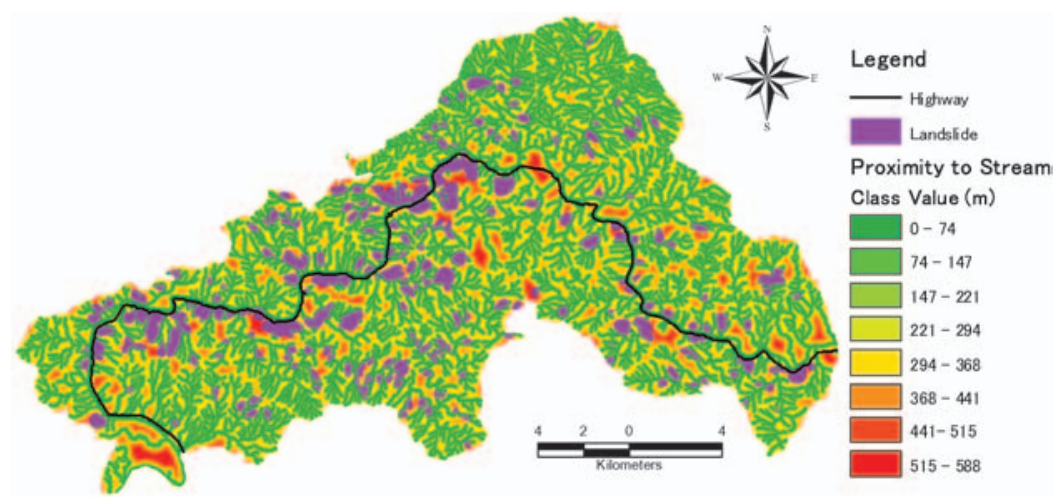

Figure 8 Distribution of landslides with variation in proximity to stream classes.
Table 5 Proximity to stream classes, landslides and Wi value.

\begin{tabular}{|c|c|c|c|}
\hline Parameter & $\begin{array}{l}\text { Parameter } \\
\text { Class (m) }\end{array}$ & $\begin{array}{l}\text { Landslide } \\
\text { Area (\%) }\end{array}$ & $\begin{array}{c}\text { Statistical } \\
\text { Index (Wi) }\end{array}$ \\
\hline \multirow{4}{*}{$\begin{array}{c}\text { Proximity } \\
\text { to Stream }\end{array}$} & $0-74$ & 41.58 & -0.2289 \\
\cline { 2 - 4 } & $74-147$ & 31.00 & 0.0834 \\
\cline { 2 - 4 } & $147-221$ & 17.67 & 0.3084 \\
\cline { 2 - 4 } & $221-294$ & 6.98 & 0.4800 \\
\cline { 2 - 4 } & $294-368$ & 2.15 & 0.4620 \\
\cline { 2 - 4 } & $368-441$ & 0.51 & 0.2308 \\
\cline { 2 - 4 } & $441-515$ & 0.10 & -0.1905 \\
\cline { 2 - 4 } & $515-588$ & 0.001 & -3.2492 \\
\hline
\end{tabular}




\section{Proximity to roads}

Proximity to a roads is an important parameter in analyzing instability along roadsides in the Himalayan region. Landslides may occur on roads and on slopes affected by roads (Pachauri and Pant, 1992; Pachauri et al., 1998; Ayalew and Yamagishi, 2005; Yalcin, 2008). A road constructed beside a slope causes a decrease in the load on both the topography and on the heel of the slope, and consequently causes an imbalance of natural earth pressure. As a result of an increase in stress on the back of the slope because of changes in topography and decrease of load, some tension cracks may be created. On the slope of a hill that is balanced before a road is constructed, instability may be observed because of negative effects such as water ingress. The proximity to road classes, percentage of landslide in each attribute and statistical indices of each attribute are shown in Figure 9 and Table 6.

\section{Lithology}

It is widely recognized that geology greatly influences the occurrence of landslides, because lithological and structural variations often lead to a difference in the strength and permeability of rocks and soils (Ayalew and Yamagishi, 2005). Lithology is one of the important factors for landslide susceptibility mapping (Lan et al., 2004; Consoscenti et al., 2007; Thiery et al., 2007; Ermini et al., 2005; Ayalew et al., 2005; Suzen and Doyuran, 2004; Eeckhaut et al., 2006; Ayalew and Yamagishi, 2005; Ercanoglu and Gokceoglu, 2004; Clerici et al., 2002; Yalcin, 2008). The study area consists of 14 types of rock formations. Lithology classes, percentage of landslides in each class and statistical indices are presented in Figure 10 and Table 7. Analysis shows that landslides are mainly observed in the Kunchha Formation (30.38\%), Nourpul Formation (20.45\%),
Dandagaon Phyllite (17.26\%), Benighat Slate (13.73\%) and the rest are in ancient alluvium, Purubeshi Quartzite, Labdi phyllites, Fagfog Quartzite, Dhading Dolomite, Hushdi beds, Jhiku carbonate beds, Malekhu limestones and Metadiabase \& conglomerate.

\section{Landslide susceptibility zonation}

Landslide susceptibility maps prepared by considering all seven parameters responsible for landslide susceptibility reveal that the landslide susceptibility index values range from -7.108366 to 3.729056. The cumulative frequency curve of landslide susceptibility index values has been segmented into five zones based on standard deviation, to yield five landslide susceptibility zones, viz. very low, low, moderate high, and very high. Their respective threshold values are $-2.713998,-1.276014,0.161971,1.599956$ and 3.729056 . The resulting map is shown in Figure 11.

It can be seen from Figure 11 that highly susceptible zones are located in the vicinity of highways. This is because of the large number of landslides in the vicinity of the highways. The landslide density in various susceptibility zones increases as the degree of susceptibility increases. From the comparison of the landslide inventory map and susceptibility map, the area in the landslide inventory map showing where landslides occurred matched the data on the landslide susceptibility map. In addition to comparison between the landslide inventory map and susceptibility map, landslide density in each susceptibility zone verifies the result. The distribution of landslides in susceptibility zones presented in Figure 12 shows the landslide density in each susceptibility zone. Landslide densities in very low, low, moderate, high and very high susceptibility zones are 0.0135 (1.2\% of landslides), 0.0349 (6.77\% of landslides), 0.0641 (31.0\% of

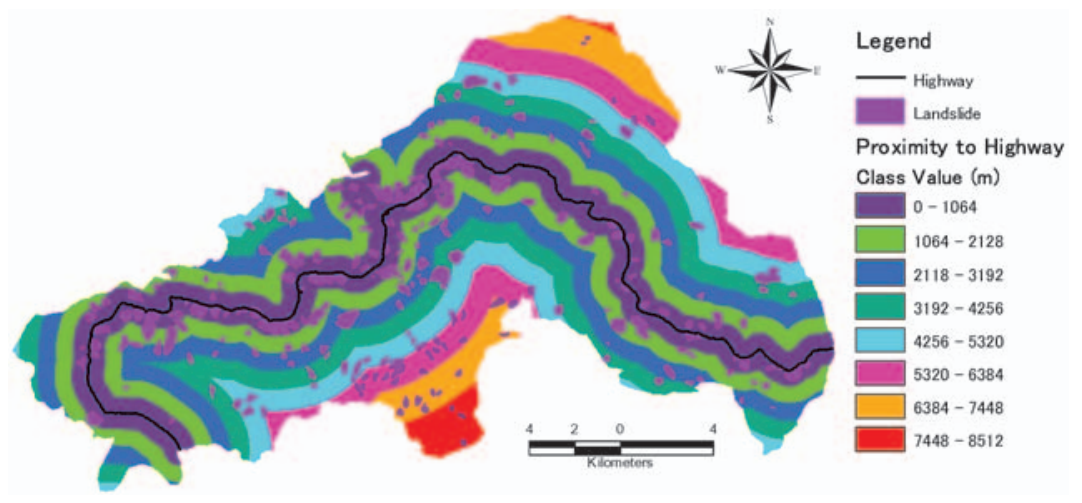

Table 6 Proximity to road classes, landslides and Wi value.

\begin{tabular}{|l|c|c|c|}
\hline Parameter & $\begin{array}{l}\text { Parameter } \\
\text { Class (m) }\end{array}$ & $\begin{array}{l}\text { Landslide } \\
\text { Area (\%) }\end{array}$ & $\begin{array}{l}\text { Statistical } \\
\text { Index (Wi) }\end{array}$ \\
\hline \multirow{4}{*}{$\begin{array}{c}\text { Proximity } \\
\text { to Road }\end{array}$} & $0-1064$ & 57.19 & 0.5468 \\
\cline { 2 - 4 } & $1064-2128$ & 17.92 & -0.3700 \\
\cline { 2 - 4 } & $2128-3192$ & 12.00 & -0.4170 \\
\cline { 2 - 4 } & $3192-4256$ & 7.97 & -0.3544 \\
\cline { 2 - 4 } & $4256-5320$ & 2.68 & -0.8346 \\
\cline { 2 - 4 } & $5320-6384$ & 1.84 & -0.5975 \\
\cline { 2 - 4 } & $6384-7448$ & 0.25 & -1.5367 \\
\cline { 2 - 4 } & $7448-8512$ & 0.16 & -1.4866 \\
\hline
\end{tabular}

Figure 9 Distribution of landslides with variation in proximity to road classes.

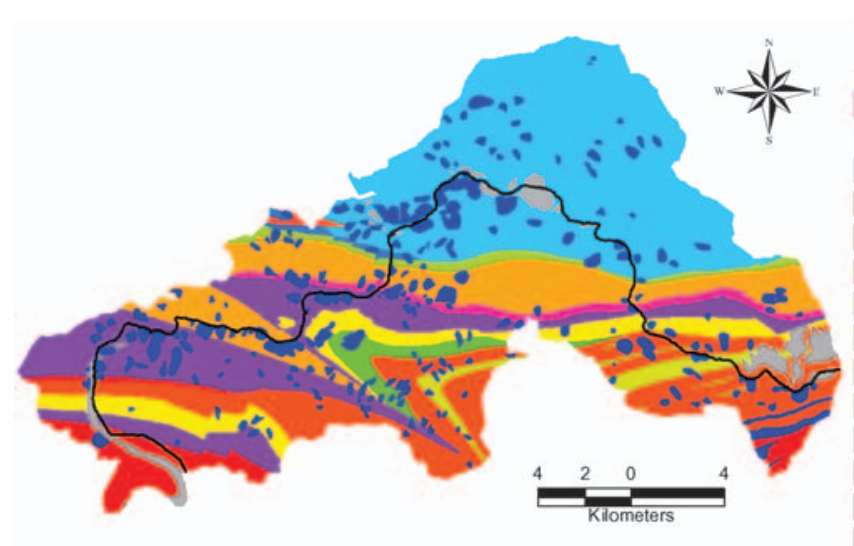

Figure 10 Distribution of landslides with variation in lithology classes.
Table 7 Lithology classes, landslides and Wi value.

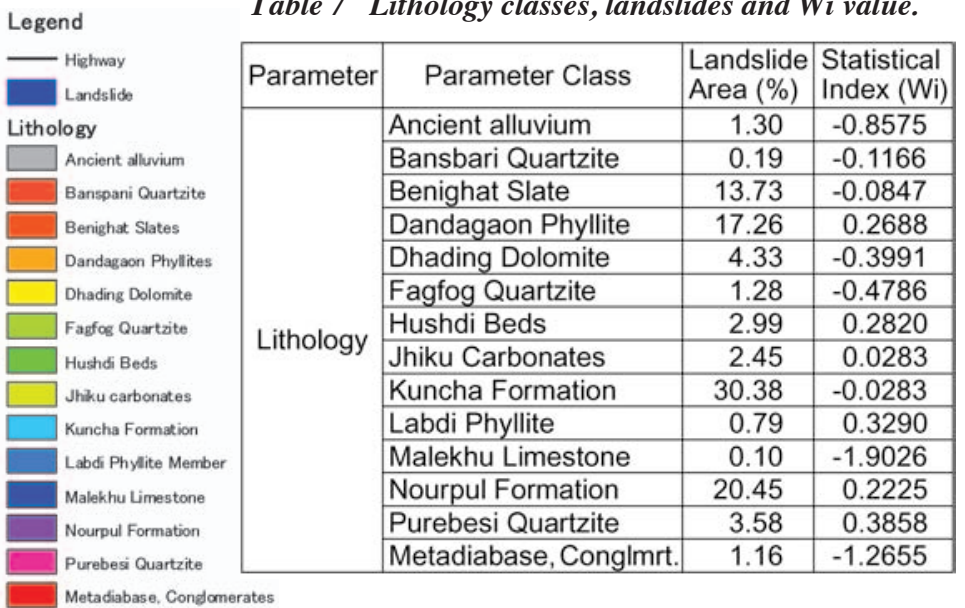




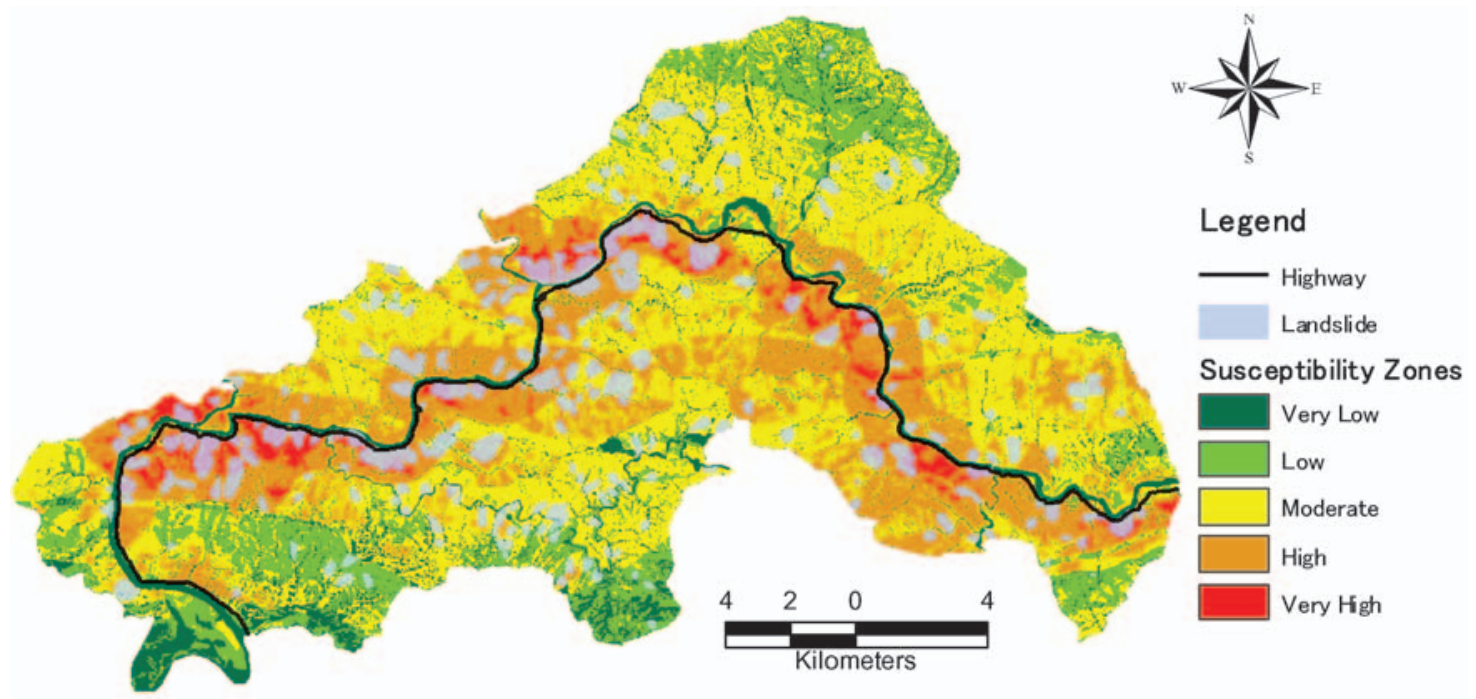

Figure 11 Landslide susceptibility zonation map.
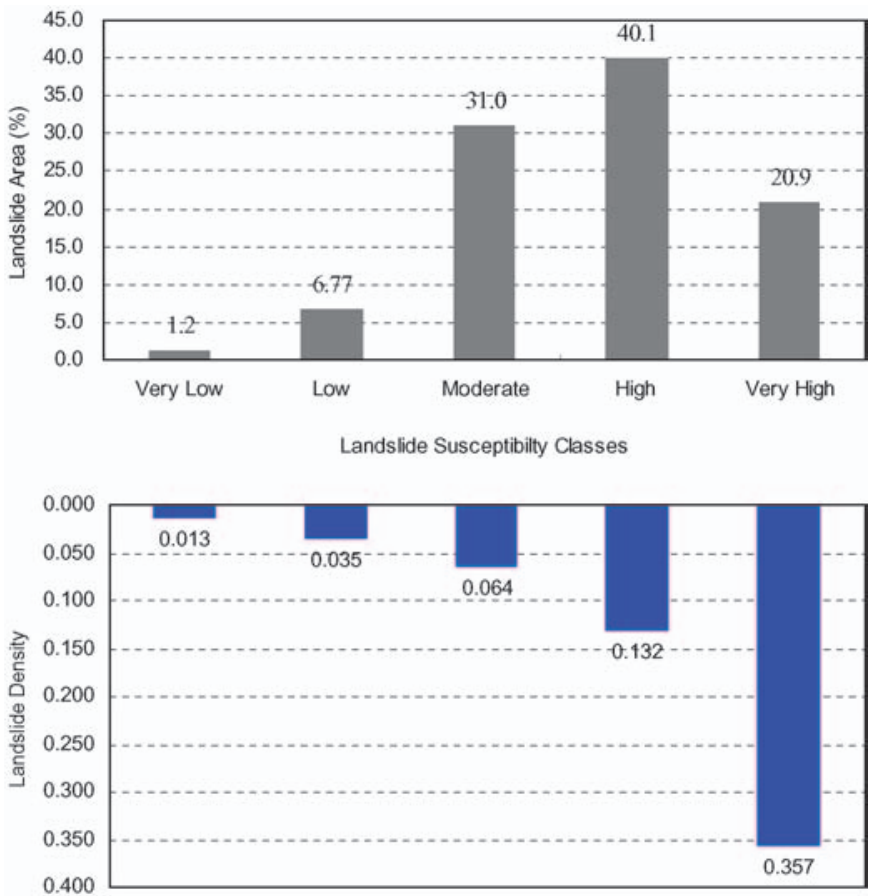

Figure 12 Distribution of landslides, landslide densities and landslide susceptibility classes.

landslides), 0.1321 (40.1\% of landslides) and 0.3566 (20.9\% of landslides) respectively. Thus, the trend of landslide distribution in various susceptibility zones verifies the results. A very high susceptible zone needs urgent preventive measures and continuous observation of slope to minimize road blockade and increase preparedness for immediate clearance of any unwanted materials on road surfaces. Emphasis should be put on slopes which are relatively more susceptible to slope failure while planning for road repair and maintenance.

\section{Conclusions}

Landslides cause enormous loss of life and property damage every year in the Himalayan region. Road services come to a halt for several days every year because of landslides and debris flows along highways. In such regions, landslide susceptibility zonation is important for delineating disaster-prone areas and planning for miti- gation measures. In the past several methods were developed and employed for landslide susceptibility zonation. Since it has already been proved that the bivariate statistical approach is the most suitable for large-scale landslide susceptibility zonation, the same approach is used in this study for regional scale landslide susceptibility zonation in the Himalayan region.

In this study, we prepared a landslide susceptibility map of a $53-\mathrm{km}$ section of highway in central Nepal by considering seven influencing parameters. This section is a major route linking the capital city Kathmandu with other parts of the country. However, this section of road is blocked by landslides for several days during the monsoon every year, disconnecting Kathmandu from other parts of the country. The Department of Roads allocates the maintenance budget for roads without any scientific/ technical assessment. As a result, maintenance work has not been effective. We hope that the methodology that we developed in this study for landslide susceptibility mapping for prioritizing roadside slope maintenance work will be useful in maintenance planning and operating the highway smoothly throughout the year, not only in Nepal but also in other regions with similar geographical and topographical conditions. Thus, preparing a landslide susceptibility zonation map along highways is a very effective tool for the planning and management of maintenance work, particularly in the Himalayan region.

\section{References}

Acharya, G., De Smedt, F. and Long N.T., 2006, Assessing Landslide hazard in GIS: a case study from Rasuwa Nepal: Bulletin of Engineering Geology and the Environment, v. 65, pp. 99-107.

Aleotti, P., Chowdhury, R., 1999, Landslide hazard assessment: summary review and new perspectives: Bulletin of Engineering Geology and the Environment, v. 58, pp. 21-44.

Ayalew, L., Yamagishi, H., 2005, The application of GIS-based logistic regression for landslide susceptibility mapping in the Kakuda-Yahiko Mountains, Central Japan: Geomorphology, v. 65, pp. 15-31.

Ayalew, L., Yamagishi, H., Marui, H., Kanno, T., 2005, Landslides in Sado Island of Japan: Part II. GIS-based susceptibility mapping with comparisons of results from two methods and verifications: Engineering Geology, v. 81 pp. $432-445$.

Cevik, E., Topal, T., 2003, GIS-based landslide susceptibility mapping for a problematic segment of the natural gas pipeline, Hendek (Turkey): Environmental Geology, v. 44 pp. 949-962.

Conoscenti, C., Maggio, C.D., Rotigliano, E., 2007, GIS-analysis to assess landslide susceptibility in a fluvial basins of NW Sicily (Italy): DOI:10.1016/j.geomorph.2006.10.039.

Clerici, A., Perego, S., Tellini, C., Vescovi, P., 2002, A procedure for landslide susceptibility zonation by the conditional analysis method: Geomorphology, v. 48, pp. 349-364. 
Dai, F.C., Lee, C.F., Li, J., Xu, Z.W., 2001, Assessment of landslide susceptibility on the natural terrain of Lantau Island, Hong Kong: Environmental Geology, v. 43, no. 3, pp. 381-391.

Deoja, B., Dhital, M., Thapa, B., and Wagner, A. (Principal Editors), 1991 , Mountain Risk Engineering Handbook: International Centre for Integrated Mountain Development (ICIMOD), Parts I and II, pp.875.

Dhital, M.R., Khanal, N., Thapa, K.B., 1993, The role of extreme weather events, mass movements, and land use changes in increasing natural hazards: A Report of the preliminary field assessment and workshop on causes of recent damage incurred in south-central Nepal, July 19-20 1993: ICIMOD, Kathmandu, pp. 123.

Dhital, M.R., 2003, Landslide Hazard Assessment in Hill Roads of Nepal: Proceeding of the Sustainable Slope Risk Management for Roads, Kathmandu, March 2003, pp. 84-94.

Eeckhaut, M. V.D., Vanwalleghem, T., Poesen, J., Govers, G., 2006, Prediction of landslide susceptibility using rare events logistic regression: A case-study in the Flemish Ardennes (Belgium): Geomorphology v. 76, pp. 392-410.

Ercanoglu, M., Gokceoglu, C., 2004, Use of fuzzy relations to produce landslide susceptibility map of a landslide prone area (West Black Sea Region, Turkey): Engineering Geology, v. 75, pp. 229-250.

Ermini, L., Catani, F., Casagli, N., 2005, Artificial neural networks applied to landslide susceptibility assessment: Geomorphology, v. 66 pp. 327-343.

Gokceoglu, C., Aksoy, H., 1996, Landslide susceptibility mapping of the slopes in the residual soils of the Mengen region (Turkey) by deterministic stability analyses and image processing techniques: Engineering Geology, v. 44, pp. 147-161.

Guzzetti, F., Carrara, A., Cardinalli, M., Reichenbach, P., 1999, Landslide hazard evaluation: a review of current techniques and their application in a multi-scale study, Central Italy: Geomorphology, v. 31, pp. 181-216.

Guzzetti, F., Reichenbah, P., Ardizzone, F., Cardinali, M., Galli, M., 2006, Estimating the quality of landslide susceptibility models: Geomorphology, v. 81, pp. 166-184.

Hearn, G.J., Lawrance C.J., 1997, Principles of low cost road engineering in mountainous regions, Transport Research Laboratory, pp.166.

Komac, M., 2006, A landslide susceptibility model using the analytical hierarchy process method and multivariate statistics in perialpine Slovenia: Geomorphology, v. 74, no. 1-4, pp. 17-28.

Lan, H. X., Zhou, C.H., Wang, L.J., Zhang, H.Y., Li, R.H., 2004, Landslide hazard spatial analysis and prediction using GIS in the Xiaojiang watershed, Yunnan, China: Engineering Geology, v. 76, no. 1-2, pp. 109-128.

Lee, S., Min, K., 2001, Statistical analysis of landslide susceptibility at Yongin, Korea: Environmental Geology, v. 40, pp. 1095-1113.

Lee, S., Ryu, J., Won, J., Park, H., 2004b, Determination and application of the weight for landslide susceptibility mapping using an artificial neural network: Engineering Geology, v. 71, pp. 289-302.

Nagarajan, R., Roy, A., Vinod, K.R., Mukherjee, A., Khire, M.V., 2000, Landslide hazard susceptibility mapping based on terrain and climatic factors for tropical monsoon regions: Bulletin of Engineering Geology and the Environment, v. 58, pp. 275-287.

Pachauri, A.K., Gupta, P.V., Chander, R., 1998, Landslide zoning in a part of the Garhwal Himalayas: Environmental Geology, v. 36, pp. 325-334.

Pachauri, A.K., Pant, M., 1992, Landslide hazard mapping based on geological attributes: Engineering Geology, v. 32, pp. 81-100.

Petley, D.N., Hearn, G.J., Hart, A., Rosser, N. J., Dunning, S.A., Oven, K., Mitchell, W. A., 2007, Trends in landslide occurrence in Nepal: Natural Hazards, v. 43, pp. 23-44.

Pathak, S., Nilsen, B., 2004, Probabilistic rock slope stability analysis for Himalayan condition: Bulletin of Engineering Geology and the Environment, v. 63 , pp. $25-32$.

Sidle, R.C., Ziegler, A.D., Negishi, J. N., Nik, A. R., Siew, R., Turkelboom, F., 2006, Erosion process in steep terrain-Truths, myths, and uncertainties related to forest management in Southeast Asia: Forest Ecology and Management, v. 224, no. 1-2, pp. 199-225.

Stocklin and, J., Bhattarai, K.D., 1977, Geology of Kathmandu area and central Mahabharat Range, Nepal Himalaya. Report of Department of Mines and Geology/UNDP (unpublished) pp. 86

Suzen, M. L., Doyuran, V., 2004, Data driven bivariate landslide susceptibility assessment using geographical information systems: a method and application to Asarsuyu catchment, Turkey: Engineering Geology, v. 71, pp. 303-321.

Thiery, Y., Malet, J.P., Sterlacchini, S., Puissant, A., Maquaire, O., 2007, Landslide susceptibility assessment by bivariate methods at large scales: application to a complex mountainous environment: Geomorphology, v. 92, pp. $38-59$.

Upreti, B.N., 2001, The physiography and geology of Nepal and landslide hazards. In: Tianchi L, Chalise, S. R., Upreti, B. N. (eds) Landslide problem mitigation to the Hindukush-Himalayas: ICIMOD, pp. 312.
Uppreti, B. N., Dhital, M. R., 1996, Landslide studies and management in Nepal: ICIMOD, pp. 87.

van Westen, C.J., 1997, Statistical landslide hazard analysis. ILWIS 2.1 for Windows application guide: ITC Publication, Enschede, pp 73-84.

Yalcin, A., 2008, GIS-based landslide susceptibility mapping using analytical hierarchy process and bivariate statistics in Ardesen (Turkey): Comparisons of results and confirmations: Catena, v. 72, pp. 1-12.

Yatabe, R., Bhandary, N.P, and Bhattarai, D., 2005, Landslide hazard mapping along major highways of Nepal: Ehime University, Matsuyama, Japan and Nepal Engineering College, Nepal, pp. 126.

Bhoj Raj Pantha graduated from Institute of Engineering, Tribhuvan University, Nepal in 2002. He joined Graduate Program in Environmental Management and Infrastructure Development Engineering, Saitama University in 2004, and completed MEng degree in 2006. He joined to Ehime University as a PhD candidate in 2006, and currently a third year PhD student. His research interests cover transportation planning, road maintenance, optimization of road alignment and maintenance, land-slides, road slope failures and appropriate technology.

\section{Ryuichi Yatabe is a Kyoto University} graduate. He was PhD (Engineering) degree in 1987 by Kyoto University. As a researcher and an academician in the field of geotechnical engineering, he has done substantial works in landslides and related soil failure problems including slope stability analysis. He has published over 100 technical papers, mostly in landsliderelated issues. His research interests include landslides, debris flows, slope failures, geoenvironmental problems, etc.

Netra Prakash Bhandary graduated from Aligarh Muslim University of India in 1993. He joined Ehime University as a postgraduate student in 1998, and completed MEng degree in 2000 and PhD (Engineering) degree in 2003, specializing in landslides and their stability. He has published more than 40 technical papers mostly focusing on landslides and slope failures. His research interests include creeping landslides, slope stability, strength properties of expansive clays, and clay mineralogy.
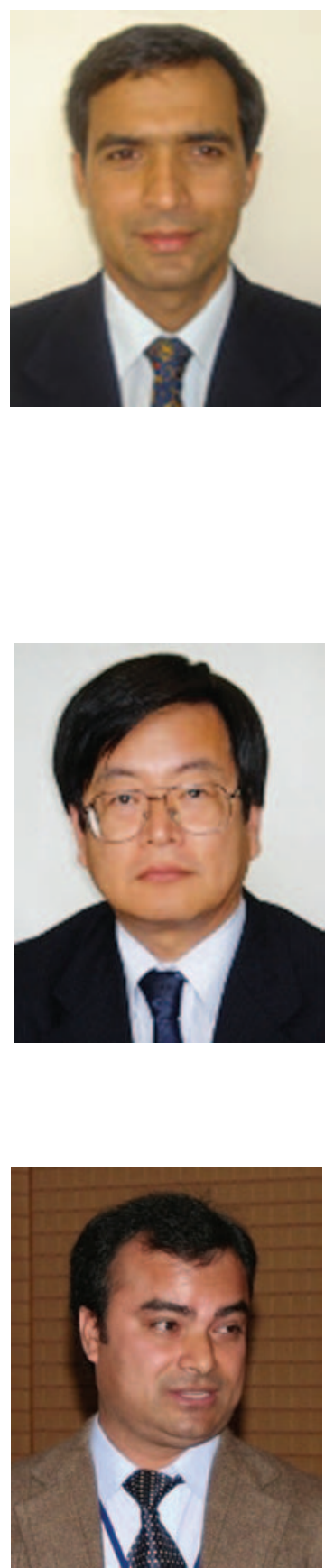